\title{
Cultural Heritage Assets: Rituals, Grinding Hollows and Other Socio-Cultural Practices in Simiyu Region, Tanzania
}

\author{
Charles B. Saanane \\ Department of Archaeology and Heritage, College of Humanities, University of Dar es Salaam, Dar es Salaam, \\ Tanzania \\ Email: csaanane@yahoo.co.uk
}

Received 11 February 2016; accepted 26 April 2016; published 29 April 2016

Copyright (C) 2016 by author and Scientific Research Publishing Inc.

This work is licensed under the Creative Commons Attribution International License (CC BY). http://creativecommons.org/licenses/by/4.0/

c) (i) Open Access

\section{Abstract}

This paper presents results from preliminary assessments in Ngasamo ward, Busega district in Simiyu region. The main objective was to assess cultural heritage assets in some areas of Bariadi district in Simiyu region. Specific objectives of the assessment are to identify tangible cultural heritage resources in Simiyu region; to identify intangible cultural heritage resources in Simiyu region; and to provide suggestions for pertinent protection, conservation and presentation of cultural heritage resources. The assessment was carried out through surveys that included documentation together with records for Global Positioning System (GPS) coordinates per surveyed locality; key informant interviews; and Focus Group Discussion. Results from the assessment revealed several worship areas that include immovable physical objects associated to ritual performance places. For example, wells like Luhuhi in Ilula village, Nkindwa biye tree in Ilula village, Magahi well in Isenge village, Isangijo hill at Isenge village, Dutwa well in Isenge village, Nyabusalu well in Igalukilo village and similar others are worship places that were revealed by informants. The assessment uncovered granite rock boulders that are being chopped off flakes for traditional medicine use in the area. Some cultural heritage sites have been identified such that a lot more needs to be explored in order to establish existence of other physical cultural heritage sites in Busega district, Bariadi district. For example, the grinding hollows, bao and the like are unique heritage resources. Such resources including undiscovered immovable archaeological objects would need presentation of sustainable preservation as well as conservation plans in line with Antiquities Acts, Antiquities Rules and Monuments of 1980 together with Cultural Heritage Policy of 2008.

\section{Keywords}

Grinding Hollows, Traditional Rituals, Rock Boulders for Traditional Medicine Use 


\section{Introduction}

This report is based on assessments along Ngasamo ward, Busega district in Simiyu region, Tanzania. Assessments involved key informant interviews together with focus group discussions in order to report aspects connected to megaliths and socio-cultural life ways of Wasukuma.

Historical Habitation of Sukuma Areas

The best scholarly views about early peopling of much of the African continent can be discerned from Linguistic and Archaeological disciplines. However, based on nature of data recovered through tangible materials, Archaeology is the best salvage for the problem. It was reported that almost all peoples occupying the southern third of the African continent, notably, from Cameroun to Nigerian sea coast in West Africa to Somalia and Kenyan coastline in Eastern Africa and southwards as far as, for example, Port Elizabeth in South Africa, speak a closely related group of languages known as the Bantu languages [1]. In addition, based on lexical, phonetic, morphological (grammatical) and syntactic resemblances, the Bantu family consists of over four hundred languages all reported to have derived from the same ancestral language known as "proto-Bantu” [1]. Assuming for such population groups descended from a common parentage, some words have common meaning, for example, the word "people" in the following languages, Congo, bantu; Rwanda, abantu; Shona (Zimbabwe) vanhu; Wasukuma (Mwanza, Simiyu and Shinyanga regions), bhanhu s [1]. All these words follow the same pattern because they derive from the form made up of the root-ntu and the prefix $b$ at-, denoting the plural [1].

Archaeological evidence of large-scale migrations can best be compared with spread of Bantu languages in Africa as the only window of hope for deciphering the said movements [1]. In due regard, speakers of Bantu languages occupied from very early times an expansive swath of territory running from the Great Lakes region of East Africa to shores of the Atlantic in Democratic Republic of the Congo [1]. Archaeological evidence points to the fact that Negroid physical type of people occupied Sub-Saharan Africa from Middle Stone Age such that from Negroid stock speakers of Bantu languages emerged [1]. Most likely Bantu languages developed through an interaction of several early Negroid communities and borrowed from one another whereby they developed new "Bantu” languages from several Negro language amalgams [1].

Archaeological evidence shows several areas of early Negro settlement in Sub-Saharan, areas of Negro communities, which may have interacted to form utterly new languages. In West Africa, for example, palaeontological evidence of Negro existence was attested at Iwo Eleru in Western Nigeria where a "proto-Negro" skull exhumed there was dated to the early tenth millennium Before Christ (9250 BC) [1]. Also in the same region, a Negroid skull was excavated at Asselar in Mali dated at the early seventh millennium (6046 BC) [1]. Other areas included the following: Rop in Northern Nigeria dated to the second millennium (-1990 \pm 120 BC) and Kintampo in Northern Ghana dated to the fourth millennium Before Christ [1].

In East Africa, the Negro emerged during the end of Pleistocene/beginning Holocene period (around 10,000 years ago) [1]. It was reported that speakers of Bantu languages moved from their original homelands and eventually, displaced as well as incorporated Khoisan and probably Sudanic stocks in big vast regions of Sub-Equatorial Africa. Such a pattern was accomplished by the end of Early Iron Age (variously referred to Early Iron Working phase) and the beginning of the second millennium BC [1] (Figure 2).

Archaeological evidence suggests that Bantu-speaking iron-using cultivators from West Africa were settled in Bukoba West of Lake Victoria in Tanzania by 500 BC [2] (Figure 1).

Mainland Tanzania was later on settled with the following population groups: Cushitic herdsmen as well as cultivators, Nilotic pastoralists and Bantu agriculturalists [2] (Figure 2). By early nineteenth-century, Mainland Tanzania was composed of population groups not identifiable to discrete compact and ethnic groups, each with a distinct territory, language, culture and political system [2]. That part of the country had population group names, which evolved to classify them as either political (inhabitants of a particular chiefdom) or simply indicated direction [2] (Figure 2). For example, those called Sukuma were "northerners" to their southern neighbours (Nyamwezi in Tabora areas) [2]. Thus, identification was absolutely relative to spatial position of a speaker as it was referred to, for example, by moving away from his/her home and dating to a new environment a person changed his/her identify like a Shambaa in Lushoto who left the Usambara Mountains commonly ceased to be called Shambaa [2]. A Turu became Sandawe in Kondoa district, Dodoma region [2].

The Role of Political Organization in Pre-Colonial Sukuma Area

The major population group that inhabited much of Shinyanga (now other parts have been designated under a new region, Simiyu) and Mwanza regions refers to "Basukuma” (singular Musukuma) and refer to their home 


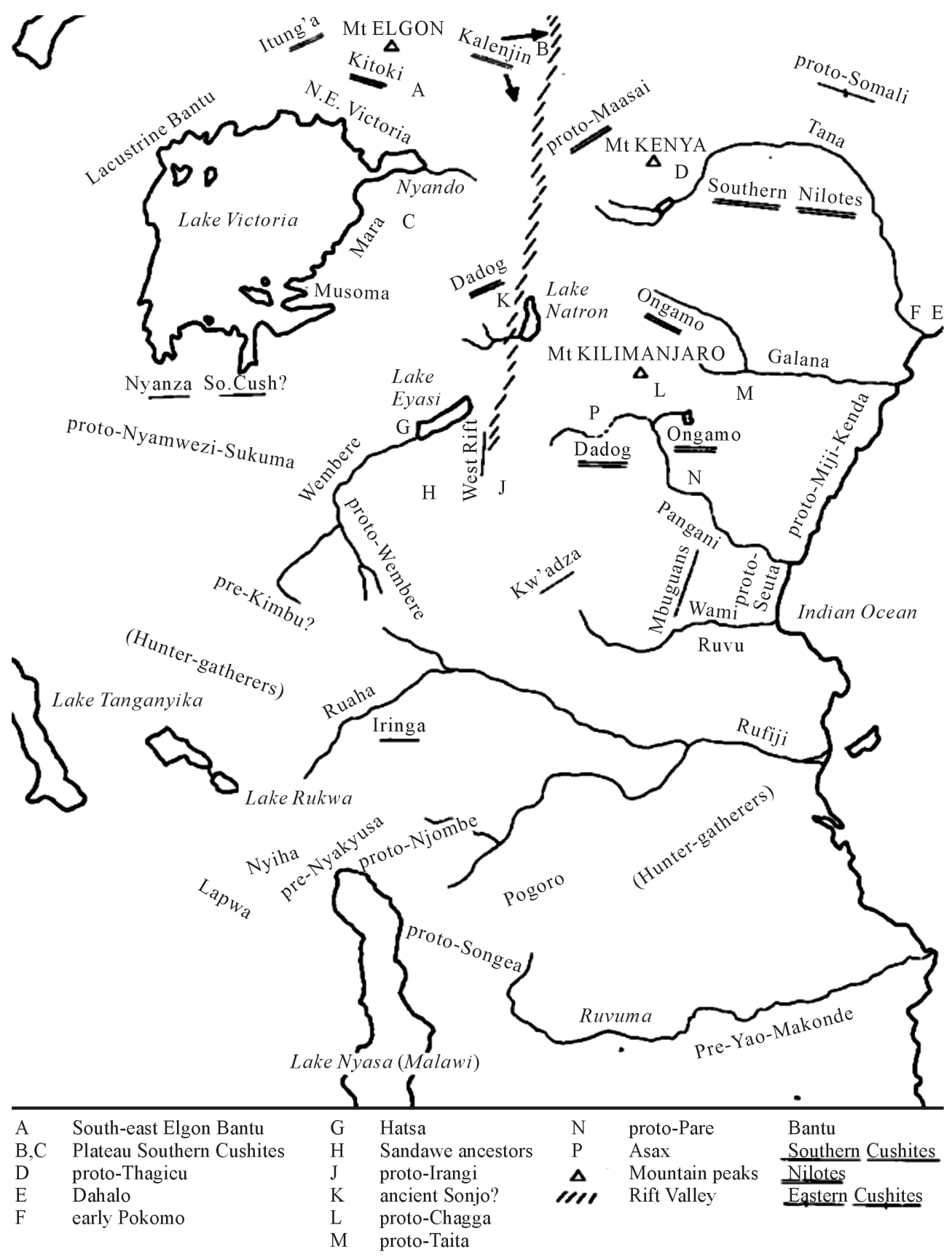

Figure 1. Probable approximate locations of peoples in east African interior (12 ${ }^{\text {th }}$ Century). Source: Adapted from Ehret (1984).

area "Busukuma" [2] (Figure 2). The term "Sukumaland" is sometimes used for the Sukuma area [2]. Recall, the name "Sukuma" literally means "north", but it has become a term of ethnic identification [2]. Furthermore, Sukuma are probably best considered as a single Bantu language with several mutually intelligible dialects [2]. Such features include a seven-vowel system, use of tone, true negative tenses, class prefixes to indicate size and restriction of double prefixes to determine situations [2].

Such a pattern was accomplished by the end of Early Iron Age (variously referred to Early Iron Working phase) and the beginning of the second millennium BC [1] (Figure 2).

The role of the chief in Usukuma has gone through many transformations since the Sixteenth Century when the area began to be organized by hierarchical chiefdoms and not villages [3]. It took place during migration of 


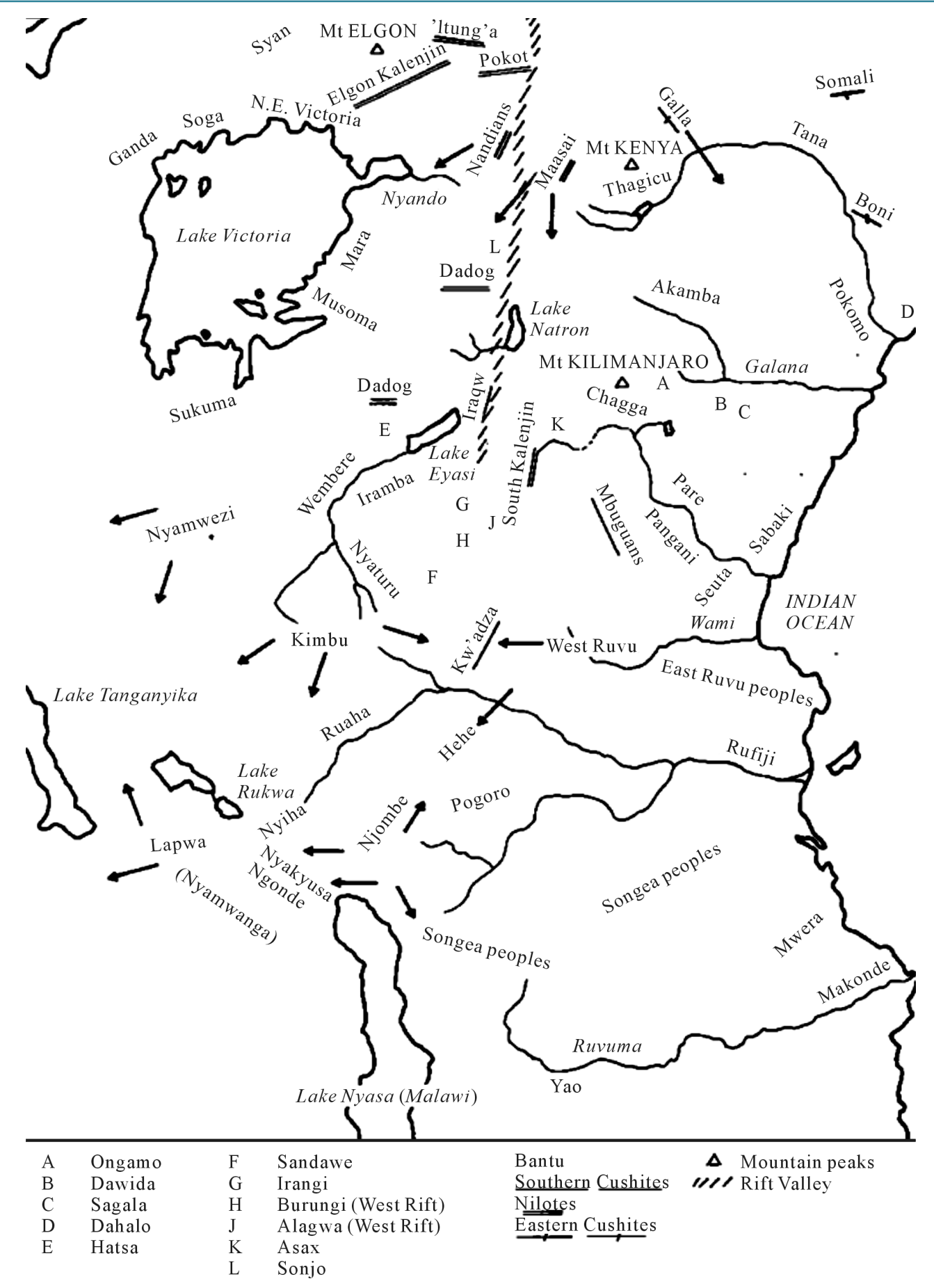

Figure 2. Probable approximate locations of peoples in east African interior (16 ${ }^{\text {th }}$ Century). Source: Adapted from Ehret (1984).

Babinza, Bakwimba, Balongo, Bangolo, and Basega Sukuma population groups [3]. The said population groups were mostly responsible for consolidating the sparsely populated areas in the Lake Victoria region and the local clans under their leadership [3]. Their exogenous customs combined with the indigenous people are now considered Wasukuma [3]. The Kisukuma word for chief, ntemi, derives from the verb kutema and literally means to cut down trees or to clear bush [3]. The behavior pattern recalls the role of early chiefs in blessing the land at the beginning of each cultivation season when the land was cleared and could also refer to cutting short of argu- 
ments following an important discussion by village elders [3].

\section{Current Population Groups}

Currently, the major ethic group is Wasukuma. Wasukuma is the largest ethnic group in Tanzania, with an estimated 5.5 million members representing about 16 percent of the country's total population [3]. Sukuma means "north" and refers to "people of the north" [3], while other ethnic groups are Wanyamwezi and Wasumbwa who are mainly found in Kahama and Bukombe districts, Geita region [3]. There are also substantial numbers of Wanyiramba, Wataturu and Wahadzabe from neighbouring regions who have settled in Shinyanga rural (Shinyanga region) and Meatu district, Simiyu region [3]. Most of the ethnic groups in the areas are Bantus who are believed to have moved into the country during the Iron Age [1]. The dominant ethnic group, Wasukuma, has both agriculturists and livestock keepers [1]. There are also a few people of Arabic origin in the region mainly found in the district and regional headquarters as well as trading centers involved in trade [1].

\section{Objectives}

\subsection{Main Objective}

The Main Objective was to assess cultural heritage assets in areas of Bariadi in Simiyu region.

\subsection{Specific Objectives}

The assessment had the following Specific Objectives:

To identify tangible cultural heritage resources in Simiyu region;

To identify intangible cultural heritage resources in Simiyu region; and

To provide suggestions for pertinent protection, conservation and presentation of cultural heritage resources.

\section{Materials and Methods}

The study was carried out through the following data collection methods:

- Surveys that included documentation together with records for GPS coordinates (see Appendix I) per surveyed locality;

- Key informant interviews through unstructured questions (see Appendix II); and

- Focus Group Discussion (please see Appendix II).

\section{Assessment Areas}

The assessment covered the following areas that included a claimed footprint around Ngasamo (Busega district, Simiyu region) and Ng'wamang'ola hill (Bariadi district, Simiyu region) as well as land between the two hills including Nyanzawe hill together with contiguous areas (please see Figure 3 and Figure 4). Other areas included Nyanzawe (Ngasamo ward) in Busega district and Ng'wamang'ola (Dutwa ward) plus contiguous areas (Igegu village) in Sapiwi ward, Bariadi district, all in Simiyu region (Figure 3; Figure 4).

\section{Results}

The assessment revealed places for traditional worship practices that included graves, trees and wells. There were some indications of archaeological materials in form of stone tools at some locations in the assessed areas. Cultural heritage assets were found on huge granite stone boulders (megaliths) with hollows for grinding cereals. A unique find included huge granite boulders in Dutwa Ward that are pecked by various people and it was claimed that resultant rock fragments (flakes and the like) are carried out such that they are used for medicinal purposes. Results are presented in detail in the following Sub-Sections:

\subsection{Graves as Places for Traditional Religious Ceremonies}

\subsubsection{Ngasamo Ward}

Ngasamo hill top has two graves, one grave of chief Ngasa and another one of his senior wife (Figure 5). The hill was named after chief Ngasa. Informants recounted that Chief Ngasa lived with his wife at Ngasamo hill. 


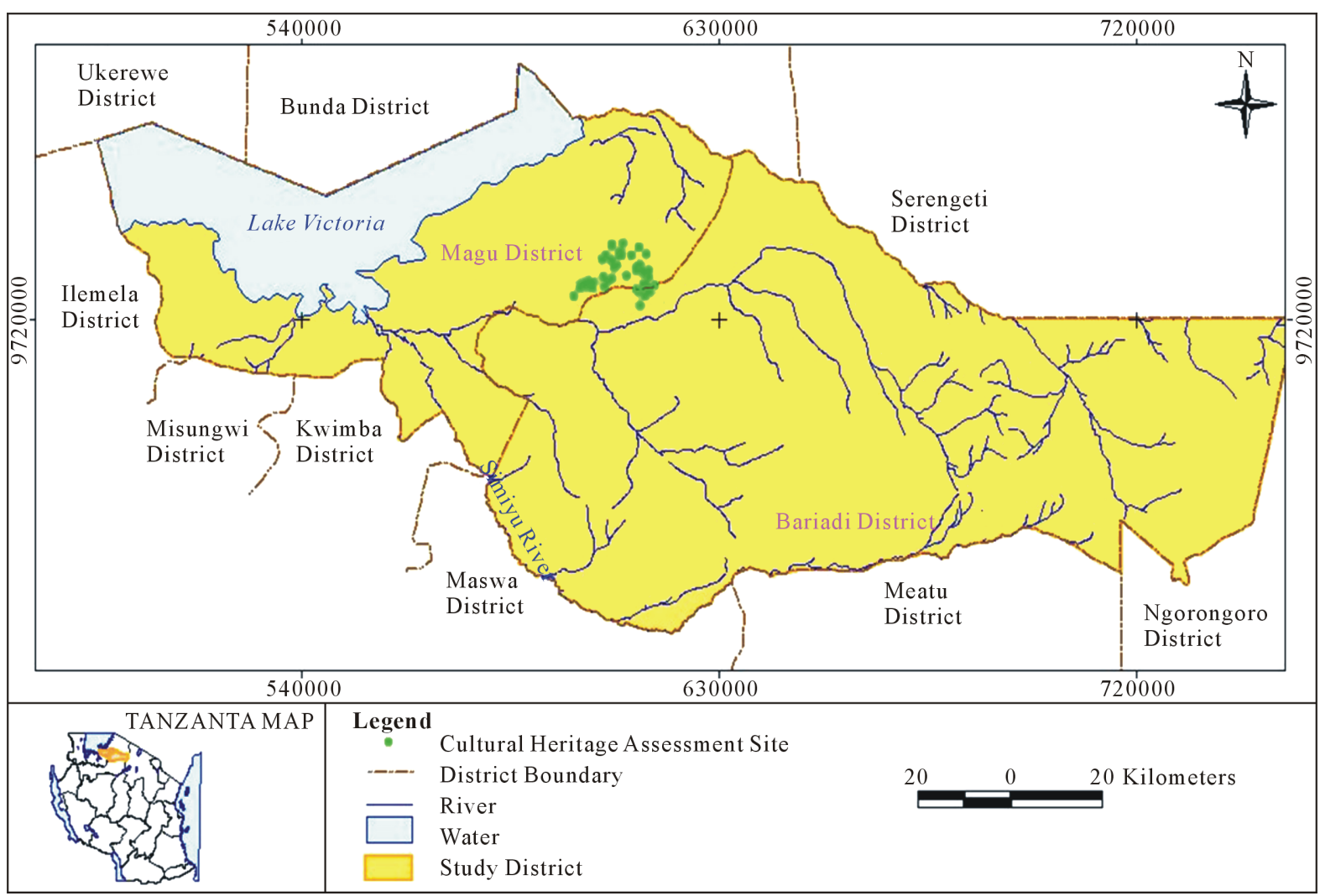

Figure 3. Cultural heritage study areas. NB: Magu district was divided into Magu for Mwanza region and Busega district for Simiyu region. The assessment covered Ngasamo ward in Busega district, Simiyu region.

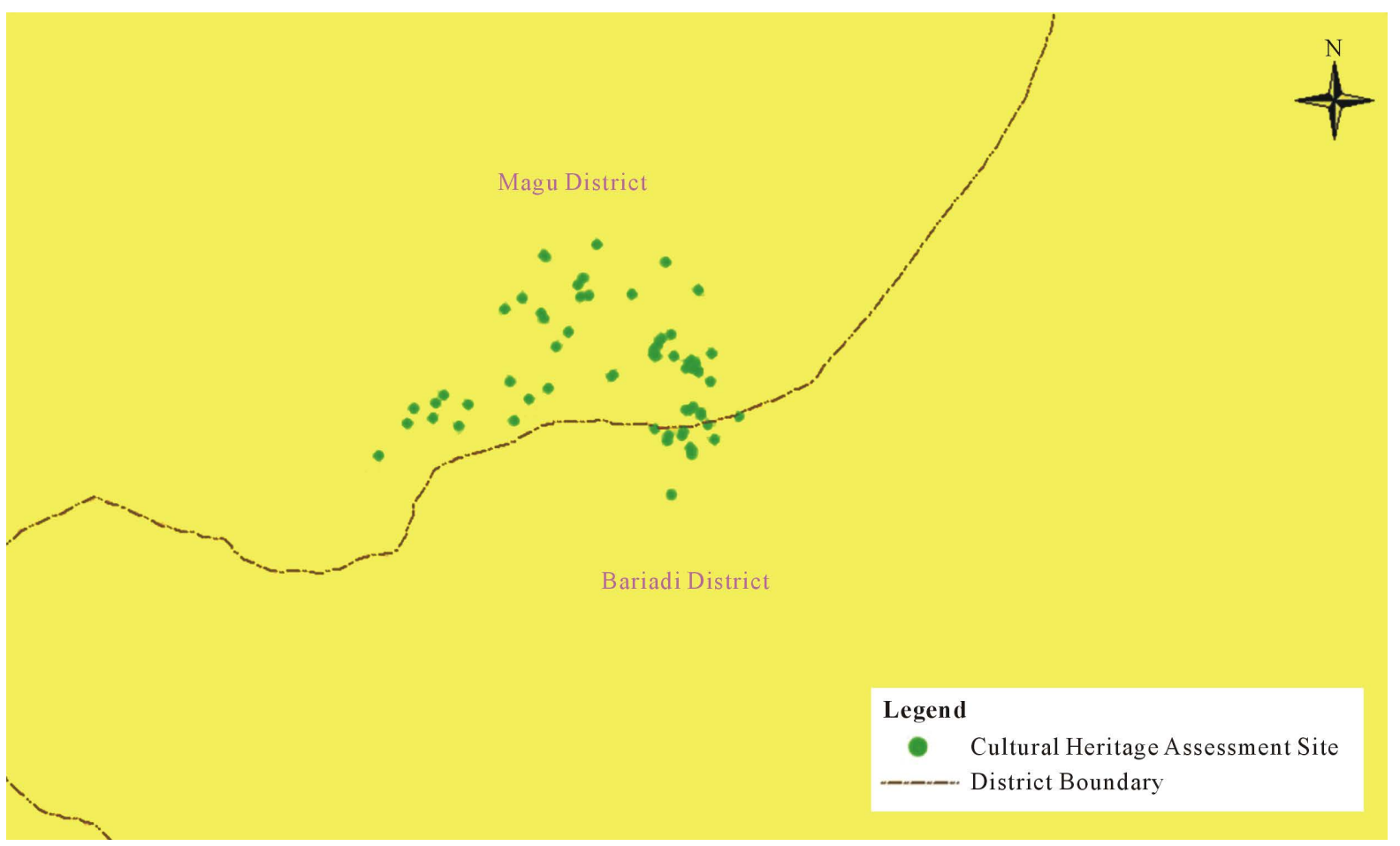

Figure 4. An enlarged view of cultural heritage study areas. NB: Magu district was divided into Magu for Mwanza region and Busega district for Simiyu region. The study covered Ngasamo ward in Busega district, Simiyu region. 
According to informants within the clan, known as Bagasamo (literally meaning people belonging to Ngasamo clan), chief Ngasa was a hunter and cultivated tobacco as well as marijuana around his residence at Ngasamo hilltop. The graves have piles of stones with built up Wasukuma traditional healers' huts (Figure 5).

The heir to Chief Ngasa is Joseph Nkwabi Mandalu, currently living at Malili Village in Busega district, Simiyu region (Figure 6). As a clan, they normally convene at least once a year, in September and carry out their traditional religious ceremonies beside the graves. It was further disclosed that other people are helped/directed by one of the relatives, a traditional healer and they pray for their requests/fortune. For example, they pray for their wishes for success in mining activities (mostly gold mining because there are artisanal gold miners at Ngasamo village), businesses, farming and the like.

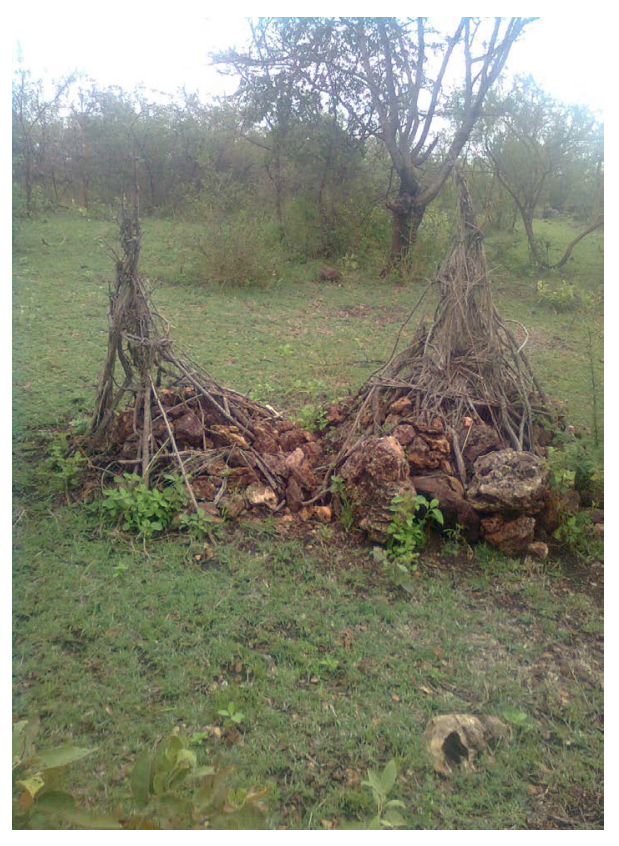

Figure 5. Ngasa and his wife's graves at Ngasamo hilltop.

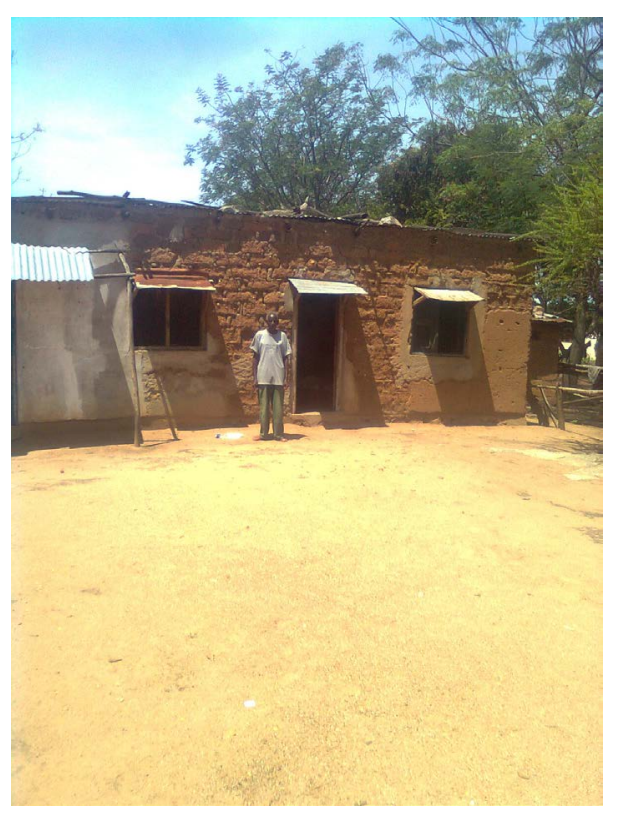

Figure 6. Heir to Ngasa. 


\subsubsection{Dutwa Ward}

West of Ng'wamang'ola foothill, there are two graves, one of Mang'ola and the other is his wife's grave (Figure 7). There are cairns spread at both graves and form a bit of a demarcation between Mang'ola's grave and his wife's grave (Figure 7). The hill was named after Mang'ola.

It was reported that Mang'ola joined Bahunda chiefdom of Dutwa area in Simiyu region and he was a traditional healer, known in Kisukuma as manga. Due to Wasukuma cosmology, they believe in his help through their traditional religion such that people go to the place and carry out their traditional religious ceremonies beside the grave as means for getting assisted for their wishes at diverse capacities, for example, for farming activities, mining, businesses and the like. The heir to Bahunda chieftaincy is Maduhu Madaki (Figure 8).

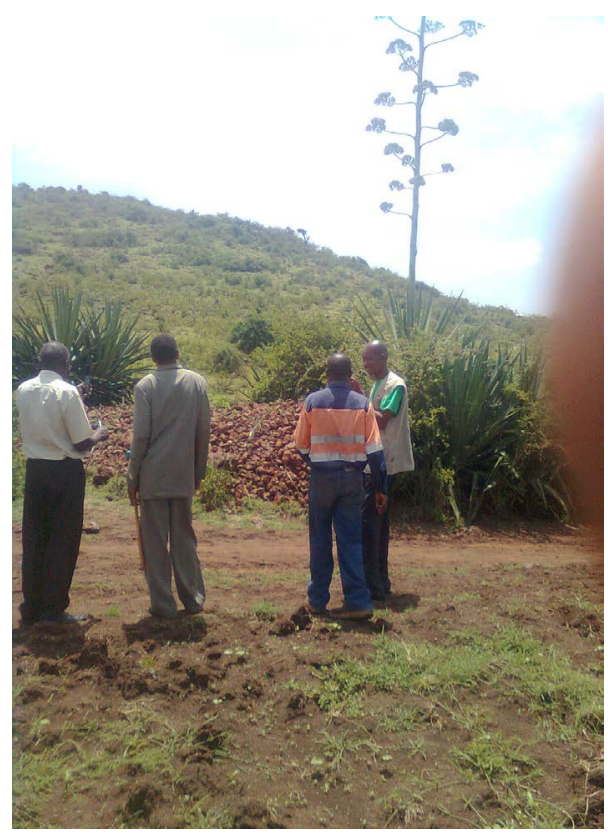

Figure 7. Graves of Mang’ola and his wife.

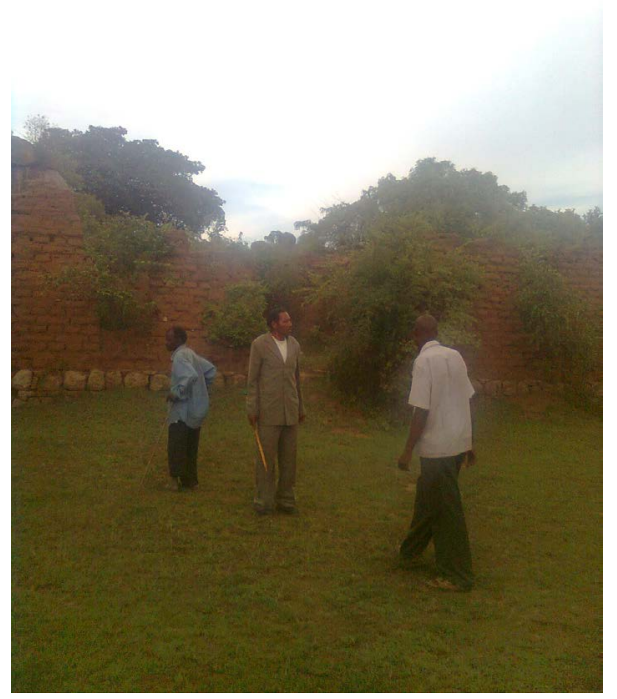

Figure 8. Chief (at middle) of Bahunda at ruins of the Chief's Palace. 


\subsection{Other Places for Traditional Religious Worship Cermenonies}

\subsubsection{Ngasamo Ward, Busega District, Simiyu Region}

Kindwa biye is a tree where they worship/pray for rain and those seeking to conceive (Figure 9). It is located at Ilula hamlet in Imalamate village, Busega district, Simiyu region at the following coordinates: Elevation 1272 metres above sea level, 36 M 0597898, UTM 9726080.

Lwinzi lukulu, locally called Luhuhi (Figure 10), is a well that never dries in Imalamate hamlet and it is a place for traditional worship. It was disclosed that Wasukuma call wells that never dry, lwinzi lukulu. Ngasa clan members perform rituals at the well besides such practices at Ngasamo hill whereby people pray for rains by end September of every year. The well is protected by a round ridge planted with trees and herbs as well as grasses as protection from erosion and the like. Its coordinates are the following: Elevation 1268 metres above sea level, 36 M 0597618, UTM 972968. It was revealed that Ngasa clan members are responsible for performing traditional rituals at Ngasamo hill beside Ngasa's grave and at Luhuhi well. There are oral accounts by local people that include a scenario that were reported. For example, they recalled that in 1960s and 1971, the well yielded ghee, a white chicken and drum beats were heard. All these were said to mean good fortune for people living around the area.

At Ng'wamalwilo B hamlet, Ng'wang'wenge village, Busega district, there is a dead tree whereby traditional ceremonies for rain making are performed every year. The last traditional ceremonies were performed in February, 2012. The place was established by one person known as Ng'wenge such that the village assumed the name Ng'wa ng'wenge (literally meaning at Ng'wenge's place). The following are coordinates for the location Elevation 1259 metres above sea level, 36 M 0600244, UTM 9730956.

At Shinyanga hamlet in Ng'wang'wenge village, Busega district, there is a traditional healer and rain maker. The following coordinates were recorded almost 200 metres away from the traditional healer's residence: Elevation 1280 metres above sea level, 36 M 0601745, UTM 9730322.

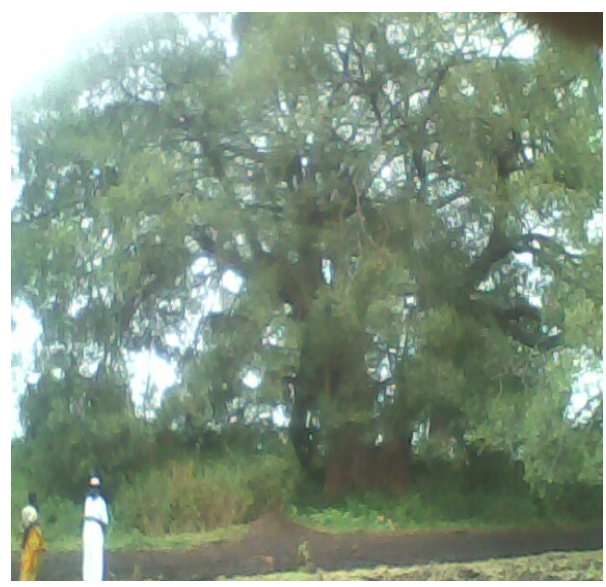

Figure 9. Kindwa biye tree, place for traditional worship.

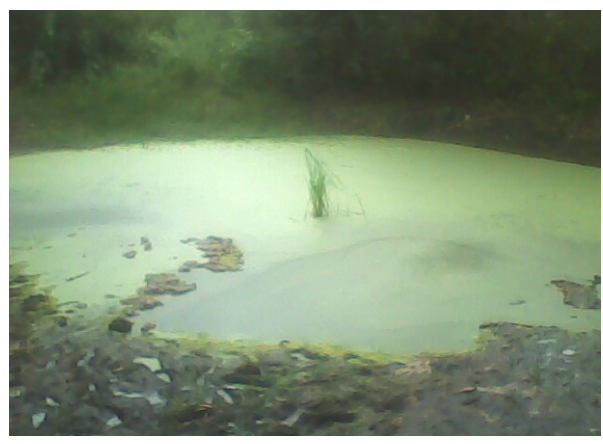

Figure 10. Lwinzi lukulu (Luhuhi). 


\subsubsection{Dutwa Ward, Bariadi District, Simiyu Region}

Places of Traditional Religious Worship

Nyabusalu wells located in Igaganulwa village, Bariadi district, Simiyu region, never get dry and they are twin wells. Informants reported that the well on the West is known as ngosha (denoting for a male in Kisukuma) or Kulwa and that on the East is called nkima (denoting for a female in Kisukuma) or Doto. There is a very old mango tree planted by the then chief Shimba over 70 years ago. The wells have encircled ridges plus grasses on their top to protect them from erosion and other weathering processes. Water from the wells is used for medicine. For example, water is fetched by using calabashes for ailments like eye sickness and for wishes to succeed in crop yields including business success. It was reported that if wells disagreed for one's presence, water would suddenly change into mud (tembe in Kisukuma) or blood or any dirt. The wells are located at the following coordinates: Elevation 1263 metres above sea level, 36 M 0607862, UTM 9723246.

In addition, it was reported that the name for the wells assume clan names within the Bahunda chiefdom. Bahunda chiefdom has two population groups, namely, Bahunda busalu and Bahunda nyama, literally meaning beads for the former and meat for the latter according to their traditional rituals and genealogical origins.

At Shayayi hill, Lubaga hamlet in Majengo village, there is a tree known as $\mathrm{Ng}$ 'hologoma or $\mathrm{Ng}$ 'hoja (Figure 11) at the Eastern part of the hill. It is a place for worship. It was reported that Bahunda clan members are responsible for traditional worship at the site and they request for any aspects in their daily lives. The place is located at 1310 metres above sea level, 36 M 0604997, UTM 9723766.

At Isangijo hill, Nyanhiga hamlet, almost 30 metres from a cave, all Dutwa people worship traditionally for various requests. The place can be traced at the following coordinates: Elevation 1289 metres above sea level, 36 M 0606395, UTM 9723674. There is a grave nearby for a person (Zaenda) who died over 100 years ago. It was claimed that the area was named after a giraffe (nhiga in Kisukuma) that fell and broke its leg to death at a rock boulder hole that had water. Such wells in rock boulders are known in Kisukuma language as chungu. All Dutwa people are used to take their seeds before planting and perform traditional rituals for good harvests. It was reported that they normally seal the hole by using rocks to save people and other animals so as to prevent them from falling into a dry hole/well thereby prevent them from dying.

At Itemelo A hamlet, Isenge village, there is Magahi well at Magahi foot hill (Figure 12). It is another place for worship. The well also never dries and recall, in Kisukuma language, such well is called as lwinzi lukulu. It belongs to Bashola clan who are spread into various areas in Simiyu, Mwanza and Shinyanga regions. Like other similar wells, the well is encircled with a ridge to protect it from erosion (see Figure 12). Informants reported

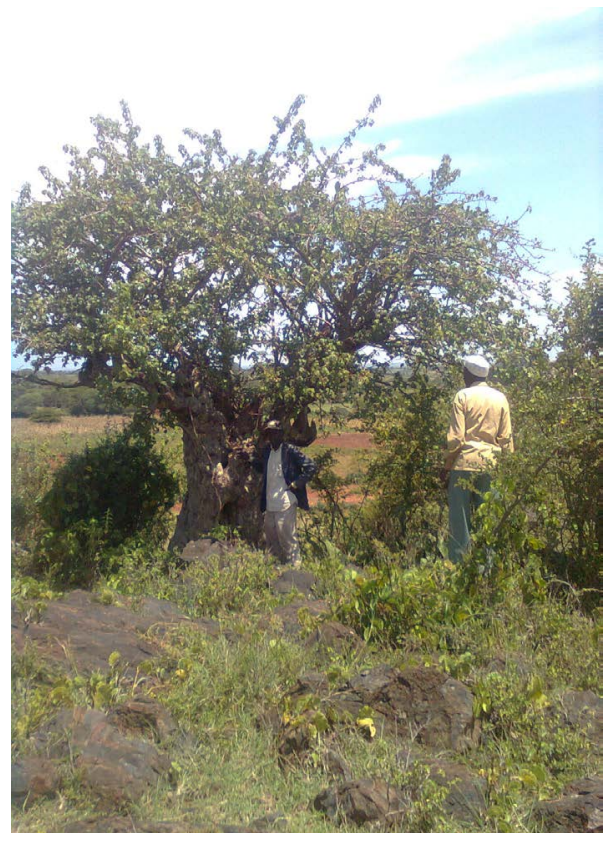

Figure 11. Ng'hologoma tree in Lubaga hamlet, Majengo village. 
that water from the well is fetched by using calabashes and other containers so as to heal eye ailments. The place is located at the following coordinates Elevation 1271 metres above sea level, 36 M 0606707, UTM 9724744.

At Itemelo B hamlet, Isenge village, there is Nama well that is still a place of worship. The site is not very far from the main road from Bariadi to Lamadi. It can be traced at the following coordinates: Elevation 1280 metres above sea level, 36 M 0607764, UTM 9727534.

At Dutwa hill, Isenge village, there is a well that has some mysteries for people (Figure 13). Like many wells in the area, the well is encircled with a ridge as protection from erosion. It was claimed that, for example, if a cow emerges from the well it is an indication that they will have good harvests. The place can be traced at the following coordinates: Elevation 1282 metres above level, 36 M 0607220, UTM 9724578.

\subsubsection{Sapiwi Ward, Bariadi District, Simiyu Region}

\section{Igegu Village}

At Nti nipu hamlet, Igegu village, there is the only tallest tree, as the name connotes in Kisukuma language whereby they undertake traditional worship ceremonies (please see Figure 14). There are several graves including Mabusi's grave, the person believed to have supernatural powers that they request for their fortune. Most people carry out worship ceremonies in pursuit for rains. Furthermore, it was reported that Mabusi was an ironsmith who had several implements for their daily lives. However, no iron material remains were spotted. Tree barks from nti nipu are always chopped off for medicine. The following are the place's coordinates: 1315 metres above sea level, 36 M 0603868, UTM 3730390.

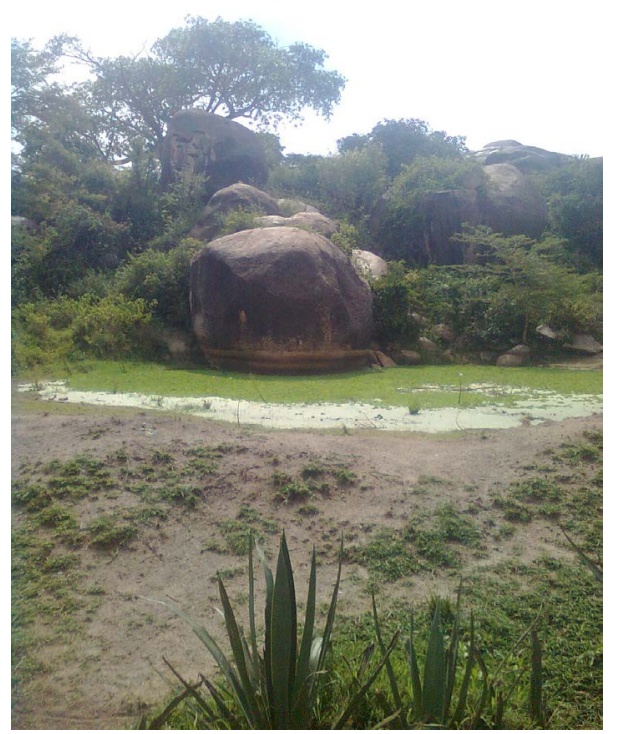

Figure 12. Magahi well.

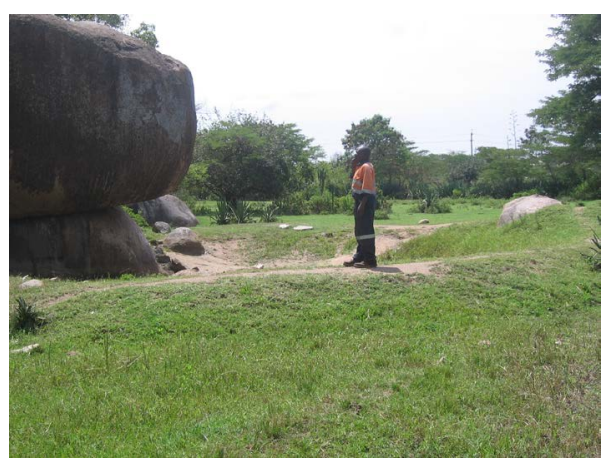

Figure 13. Well at Dutwa hill. 
At Jibiso hamlet in Igegu village, Kihalawa hill is a place for worship for many people (Figure 15). The place has many trees and granite rock boulders. The place is located at the following coordinates: Elevation 1280 metres above sea level, 36 M 0602152, UTM 9732858.

At Mpilingito hamlet in Igegu village, there is a grave of Minzi $k u$ ntwe whereby people perform rituals for rain making (see Figure 16). The name is after a person who was a great rain maker and literally, his name means water on head. Many people from various locations such as Igegu village and Kijilishi at Mkula village attend to such traditional rituals for rain making. They make contributions for all necessary items for sacrifice in the desired traditional rituals. The grave is left untouched while surrounding areas are cultivated (Figure 16). The place can be accessed at the following coordinates: Elevation 1309 metres above sea level, UTM 9730616.

\subsection{Other Cultural Heritage Assets}

\subsubsection{Ngasamo Ward}

Secondary data are the only reported so far because primary data from the current reconnaissance work did not

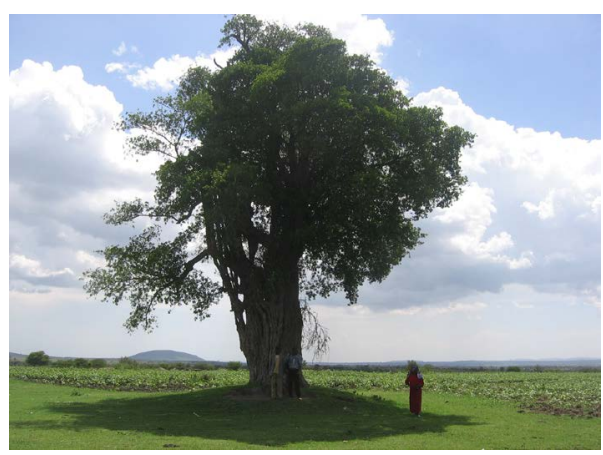

Figure 14. Nti nipu at Igegu village.

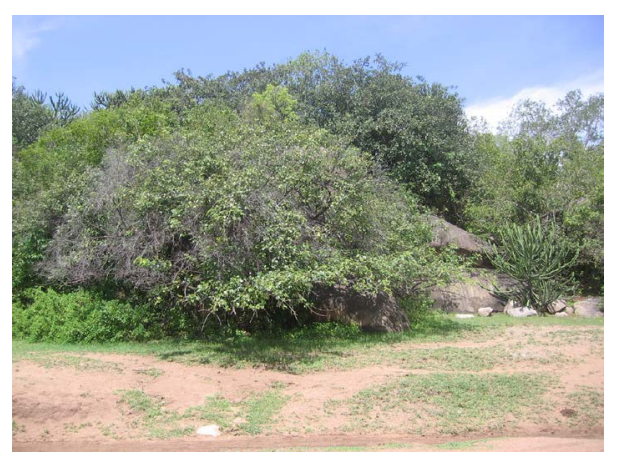

Figure 15. Kihalawa hill.

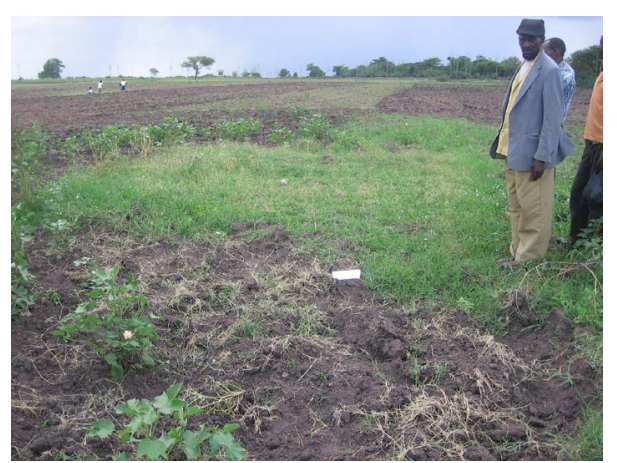

Figure 16. Minzi Ku ntwe's grave (piece of land with grasses). 
reveal archaeological remains on surface. Thus, former archaeological research works [4] reported stone tools earlier in date than Later Stone Age at two sites in Ngasamo vicinity. A few tools were found by the team on the East bank of Duma River tributary north of crossing of Ngasamo Goldmine [4]. Also between 15 and 1.2 kilometres due West-North-West of Ngasamo along Nassa road, they [4] discovered artifacts attributed to Middle Stone Age. Furthermore, Nyang'oma rock shelter some two kilometers South-West of Shigala village, along Nyashimo to Ngasamo/Bariadi road, two adjacent small rock shelters have rock paintings with a lot of Later Stone Age materials [4] [5]. Other materials were recovered from the locality and included Iron Age pottery; vertebrate fossil remains; shell fragments belonging to nacreous fresh-water bivalve; a few shell fragments of large land-snails; and ostrich egg-shells [4]. The charcoal sample revealed dates at the lower stratum to be 2640 \pm 120 Before Present (B.P.) or 690 Before Christ [4].

In addition, at Mwamajo rock shelter, about one kilometer to the South of Shigala village, there is a gong and immediately in the vicinity there is another rock shelter with red paintings, while the floor yielded quartz stone artifacts, iron-smelting remains, pottery remains and bone fragments [4]-[6]. Rock gongs were also found in Moru Kopje areas, Serengeti National Park, Mara region and are believed to have been used as musical instruments [4]. The proponent [4] suggested dates of rock gongs to be fourteenth or fifteenth century A.D. based on their dated occurrences in Uganda and Kenya [5].

\subsubsection{Dutwa Ward, Bariadi District, Simiyu Region}

\section{1) Grinding Hollows}

Some places were found with grinding hollows at large granite boulders for grinding cereals. They used them in ancient to contemporary times. For example, at Msanga A and Msanga B hamlets (all of Sengerema village) as well as Magahi hill, such grinding hollows on granite rock boulders were spotted (see Figure 17 and Appendix I for GPS coordinates).

A characteristic feature on rocks sighted in Dutwa Ward is a grinding hollow that is a depression larger than a cup-mark ground into a flat or a bit convex outcrop of granite bedrock (Figure 17) [6]. Groups of depressions aligned in two rows (Figure 17) and number of hollows varied from forty hollows and above. [6] suggested that as long as grinding hollows have the same overall shape like grinding surface of portable grinding stones, they could be called stationary grinding stones. In terms of outline, the depression may be oval or sub-rectangular
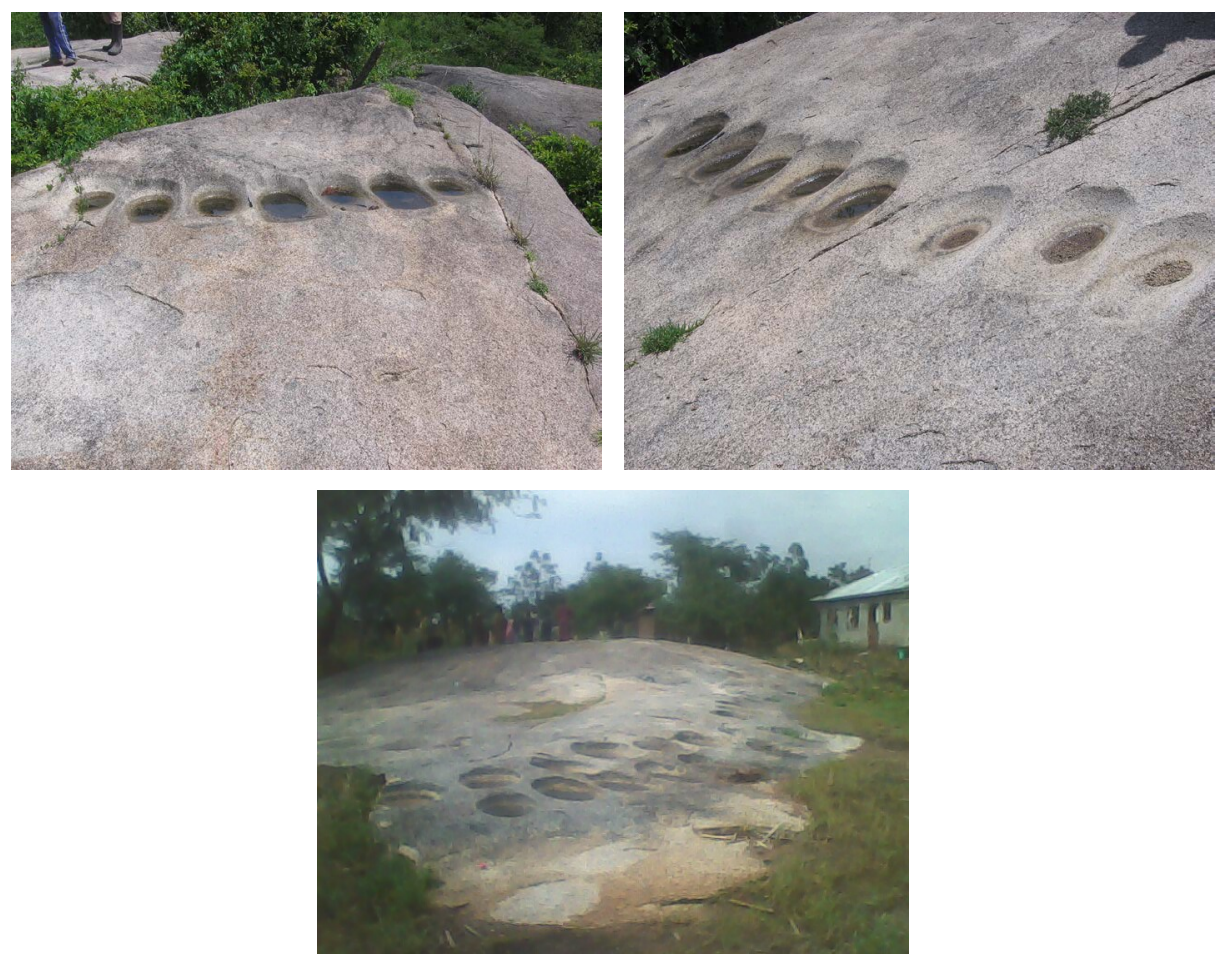

Figure 17. Grinding hollows from various locations. 
(see Figure 17 and Figure 18). Wasukuma have different terms for various kinds of grinding stones, for example, a portable stone for grinding snuff, traditional medicine and similar substances is known as izunzu (plural mazunzu). Iwe (plural mawe) is a large, basin-shaped stone for grinding maize, millet or sorghum, while grinding hollows are called manhe or g'homango (see also [6]). They [6] reported such occurrences in Mwanza region. For example, at Kalumwa in Sengerema district, Nyamasale hill (Sengerema district), Gaetje's dairy farm at Kamanga as well as Nyamatongo in Sengerema district [6]. Like occurrences reported by [6], they are not in use today and in later years, Wasukuma started using portable grinding stones with millers for grinding cereals. The informants said that such grinding hollows were deepened by young ladies who were hard workers. Expected suitors stood by their side in order to spot such hard working young ladies that they can choose from to marry. It was different from the traditional dances at night whereby boys chased girls in order to choose those they love, a pattern known in Kisukuma as chagulaga. It was argued that chagulaga was not as a serious pattern for preparations into betrothal like spotting a young lady to marry later on. Currently, it was reported that Wasukuma youth are using other means to get fiancé due to many socio-cultural transformations.

Secondary data help to decipher and compare from the primary data revealed from the reconnaissance surveys of this work. For example, other parts of Africa that yielded grinding hollows include Zambia and Nigeria [6]. Those in Nigeria were reported to have had been associated with percussion boulders and rock paintings as part of the marriage ceremonial complex [6].

Through key informant interviews during reconnaissance surveys, Dutwa grinding hollows were reported associated with marriage complex whereby men stood beside women who were grinding cereals to select the best pair witnessed from a good grinder who produced deep hollows. It was further revealed that such a pattern was a sign of a hard working woman suitable for sustaining the expected family chores. Dates for such occurrences seem to post-date contemporary settlements based on oral accounts reported by [6], a pattern that could be true for Dutwa grinding hollows.

At Magahi hill, there are hollows also reported to have been used as grinding stones on rock faces below at two granite rock boulders (see Figure 18). The remains are located at the following coordinates: 1289 metres above sea level, 36 M 0606606 and UTM 9727688.

\section{2) Traditional Game (bao in Kiswahili and isolo in Kisukuma) Sites}

The reconnaissance survey at Msanga A, Sengerema village uncovered on a rock surface a game, known in Kisukuma as isolo. Also at Ng'wanhiga hamlet (Majengo village) at Kandawa hill and Nyalule hill in Ng'wanhiga hamlet, Majengo village (see Appendix I for GPS coordinates). The said traditional game sites are located in hill sites whereby people enjoyed shade and breeze as experienced during the survey. Also, like

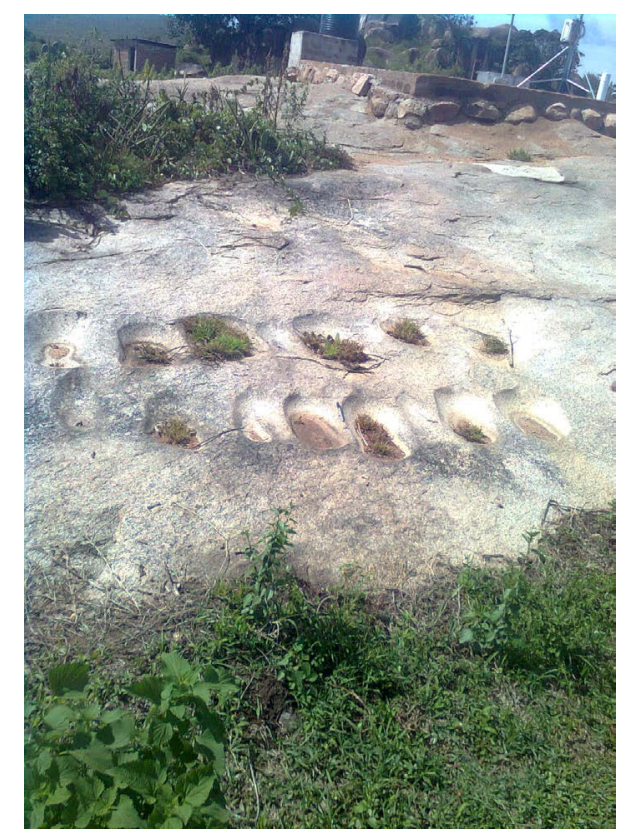

Figure 18. Grinding hollows at Magahi hill. 
grinding hollows, a traditional game (bao) has small hollows that resemble current bao hollows on wood. They have deep pits that could hold dices (kete in Kiswahili), like round seedlings or rocks.

At Nyamhunu in Igalukiro (Dutwa) areas, there is a cave and a rock, which was reported to have been used as a drum [4]. Recall, [4] suggested dates of rock gongs to be fourteenth or fifteenth century A.D. based on their dated occurrences in Uganda and Kenya.

\subsection{Unique Materials}

\subsubsection{Dutwa Ward}

\section{1) Unique Rock Boulders for Traditional Medicine Purposes}

The reconnaissance survey uncovered unique rock boulders after being led by key informants at Msanga A hamlet whereby two rock boulders, one very huge and tall and another one, small and short, are used for medicinal purposes (see Figure 19). The small rock boulder's height does not reach the depression seen at almost half way of the big boulder. It was claimed that people chopped off either of the rocks to get rock fragments and for one wishing to get a baby after failing for many years, she has to tie the piece of rock at her back in order to be successful in the desired wish.

\section{2) Claimed Human Footprint}

Key informants claimed that at Kindilo hill (1260 metres above sea level, 36 M 0605559, UTM 9723204) there was a human footprint along a huge rock face (Figure 20). Relocation of the claimed rock boulder was directed by one of elders who looked enthusiastic to the find. However, upon reaching and carrying out close examinations, it came out to be a granite rock boulder that dates many hundreds of millions of years ago (also confirmed by one Geologist) such that no protohominin had evolved. Geological formation and dating of the granite boulder precludes the claim for hominin existence by then. Furthermore, even primate evolution started with Prosimians some 65 million years ago. Ascertained pro-hominin evolution is from known from Sahelanthropus chadiensis around 7 million years ago from Chad deposits followed by Tugen hills discoveries in northern Kenya deposits dated at 6 million years ago represented by Orrorin tugensis. The only indisputable hominin footprints were discovered by Dr. Mary Leakey and her team in 1979 from Laetoli in Ngorongoro Conservation Area, Arusha region in northern Tanzania dated at a nitrocarbonatite rock surface 3.59 million years ago and were interpreted to have had been made by hominins named Australopithecus afarensis. Other late dates for hominin footprints have been reported in Engaruka, Monduli District, Arusha region in northern Tanzania from deposits tentatively claimed to be dated over 120,000 years before present. Further examinations showed that

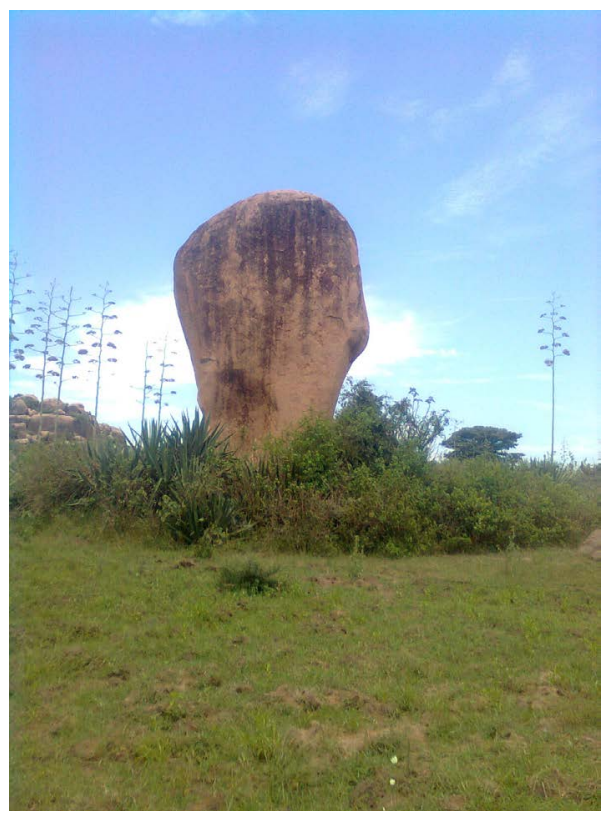

Figure 19. Rock boulders for traditional medicine purposes. 
weathering patterns to such mineralized rock boulder caused cracks that could lead one to imagine that a crack looked like a hominin footprint. Thus, there is no such thing as a human footprint at a granite rock face (see Figure 20).

\section{3) Ipilinga Lya Balya Banhu}

At Isenge B hamlet, Isenge village further East of Igalukilo village (Dutwa centre) in hills, there is a cave called in Kisukuma ipilinga lya balya banhu, literally meaning a man eater cave (1289 metres above sea level, 36 M 0609073, UTM 9724394). The cave has three entrances that were used by people (Figure 21). Currently, a lot of huge bats are permanent dwellers in the cave. It is believed that many people died and purported to be eaten by man eaters. At the hill top, bees were still there. It was reported that during old times, bees and caves were used during local wars with Maasai warriors who raided villages. Thus, bees were used by Wasukuma as biological weapons in defense against Maasai invaders who were cattle raiders in Sukumaland. Informants disclosed that the British colonial administration stopped use of the cave for whatever means.

\section{4) Chief's Residence and Office (Ikulu) at Nyamiselya}

Nyamiselya in Isenge village, was the Bahunda chief's (ntemi means chief in Kisukuma) homestead and official residence [(ikulu in Kisukuma) 1302 metres above sea level, 36 M 0608821, UTM 9724048]. It was further informed that Chief Sagayika established the place followed by heirs Balina, Mushuda, Ileme, Buyunge and Kasili. Ntemi Kasili was the last to stay at Nyamiselya. However, the house is in ruins/dilapidated as shown in Figure 22.

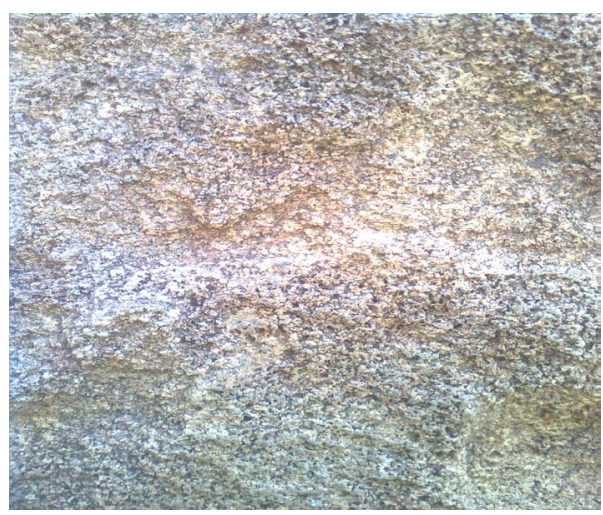

Figure 20. Claimed Hominin footprint.

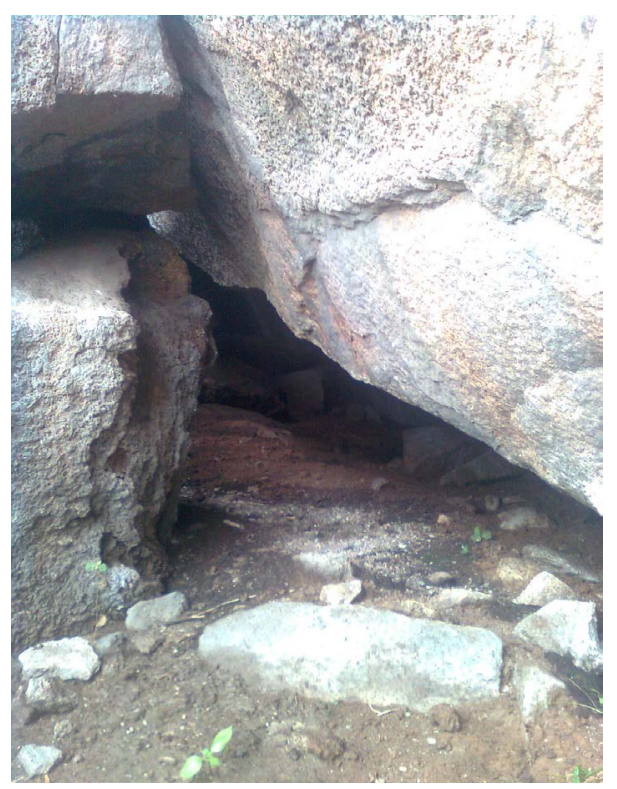

Figure 21. Ipilinga lya balya banhu. 


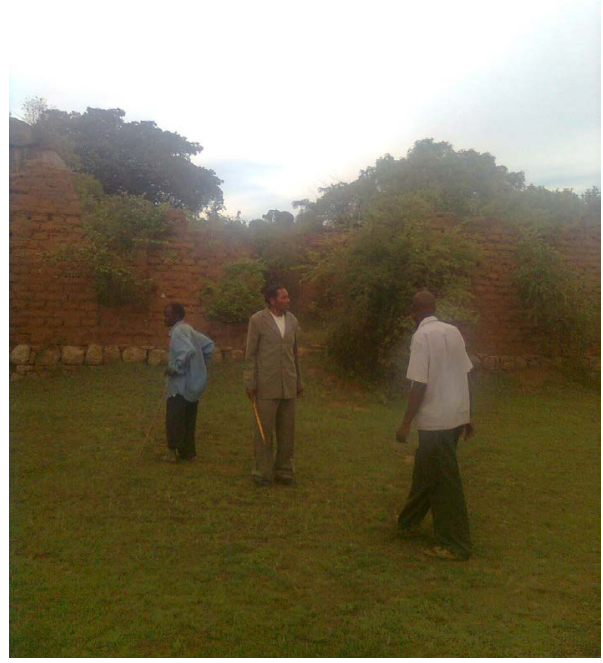

Figure 22. Bahunda Ntemi Headquarters (Ikulu) at Nyamiselya. NB: The current ntemi is a shown at the middle in the left photograph.

\subsubsection{Sapiwi Ward}

At Nti nipu, there could be remains of Later Stone Age and iron working (smelting) remains because Mabusi was reported to be an ironsmith. However, the place showed stone fragments that were not diagnostic or attributable to archaeological remains. Probably iron slag materials and similar others used in the iron smelting works could be recovered upon archaeological excavations (Elevation 1280 metres above sea level, $36 \mathrm{M}$ 0602152, UTM 9732858 Nti nipu photograph see Figure 14).

\subsection{Results from Interviews and Focus Group Discussions}

\subsubsection{Biography and Establishment of Chief's Residential Area}

Through key informant interviews, it was revealed that Chief Ngasa founded the area and established his settlements at Ngasamo hill. In Kisukuma, the term ntemi is singular and batemi is plural. He had two wives who stayed with him. Chief Ngasa was basically a hunter but by using wooden hoes (from gembe and migunga hard woods), he cultivated tobacco and marijuana at Ngasamo hill top. He dug a well for water supply at the hill top. He lived there before 1909 at 40 years of age. It was reported that he came from South known in Kisukuma as Dakama, which means Tabora. His first wife bore two boys and two girls and his younger wife bore 2 girls and four boys.

Chief Ngasa died before British colonial rule in Mainland Tanzania (then known as Tanganyika). His second wife was also buried there (see Figure 5). It was reported that he was buried at Ngasamo hill and his second wife went to her home place at Sengerema in Kwimba district, Mwanza region.

The origin of the name Ngasa was reported to be an Anglicization from the name Ngasa whereby Europeans asked in poor Kisukuma language that "nani alimo?" Literally meaning, "who is there at that place (the hill)?" Wasukuma responded that "alimo Ngasa", implied that Ngasa is there but Europeans connected to the word Ngasamo.

Most chiefs in African societies were custodians of cultural heritage and official leaders. Most had magical and medicinal powers. Thus, Chief Ngasa was no exception. Recall, it was reported that in September or so for every year, clan members convene and perform traditional rituals beside Chief Nagas's grave. One of the relatives is a traditional healer who directs the performances. She also helps other people who wish for their fortunes beside the grave such as artisanal miners (mostly gold miners undertaking such works at Ngasamo village deposits), business fellows and requests for rains. As already reported in the Sub-Sections before, at Luhuhi well in Ilula village, Ngasamo clan members are also responsible in carrying out request for rain making through tradi- 
tional prayers. They reported that by end-March, 2012, they performed such traditional prayers at Ilula and later on it rained heavily.

Their rituals involve local beer (known as walwa wa swizo in Kisukuma), millet, a topi, marijuana, tobacco, an eland's whisk, shilungu (a special traditional bracelet), special spears used for drilling wood and so on. Almost 4.5 metres and 2.5 metres away from the grave there are charcoal remains from rituals performed in February, 2012. Currently, the heir to Ngasa is Joseph Nkwabi Mandalu (see Figure 6). He lives at Malili village on the way to Nassa not very far from Ngasamo village.

Recall, it was reported that at wells, for example, at Luhuhi in Ilula village, Ngasamo Ward, in September for every year they perform traditional rituals and build special small huts designated for traditional worship ceremonies. They slaughter white chicken and continue with rituals in request for rains.

It was reported further that Mang'ola was a person who went to Igalukilo area with his wife to settle. With his wife and younger brother, he came from Mang'ola in Babati district, Manyara region, northern Tanzania. He was from Wataturu ethnic group. He was invited by Bahunda (Chief Sagayika father of Balina) in Isenge village. Mang'ola was named by Wasukuma after his place of domicile. Bahunda royal family incorporated him in their royal family. He was a traditional healer (known in Kisukuma as mmanga). He settled at the hill that was named after him, Ng'wamang'ola.

It was reported that because of belief in supernatural powers after Mang'ola, many people from around Tanzania flock the place and pray for their requests/wishes. It was informed further that because many people succeed, such reported successes make other people to flock the place.

Nyabusalu well at Igalukilo had legendary accounts. It was reported that water was used for healing by fetching through a calabash and splash to eyes of the blind person. Furthermore, water from the well can be sprinkled over farms or businesses for good harvests and prosperous businesses, respectively. If a person is disliked by the well and fetches such water, he/she will find such water turning into blood or becomes dirty or will turn into a traditional hut (tembe). If the well accepts a person, such person will see fish such as cat fish but should not fish it. It was reported those who tried to remove fish from the well and took to their homes, upon cooking, such fish remained live. Then, it would disappear. At a certain time it was reported that one lady found a beautiful baby girl by the well and exchanged such girl to her baby. Upon reaching home in order to sit down, a voice was heard inquiring for reasons she took the baby girl from the well. She was advised to return the baby girl to the well. When she so did, she found her baby dead.

\subsubsection{The Chief's Traditional Power and Strength}

It was reported that in order to understand traditional power and strength of the relationship of the chief and his chiefdom, one has to recognize that the key to sustaining power was controlling the state of mhola. The word mhola derives from the Kisukuma verb Kuhola, meaning to be healthy, thriving, and it is also part of Wasukuma greetings of another person. If the Chiefdom was in such state, the chief's position was secure and if not he could be dethroned in favor of another family member. The chief was not infallible even though his subjects honored his sacred relationship, which linked the powers of god and of his ancestors with the welfare of his people. The magico-religious or semi-divine relationships are revealed to his subjects in several ceremonies, for example, those taking place at his enthronement, before battle, during a period of pestilence, at the birth of twins, and especially during the seasonal ceremonies connected with the annual agricultural cycle. In pre-colonial times, a newly designated Wasukuma Chief went through the following series of ceremonies or rights of passage:

\subsubsection{Royal Installation Ceremonies}

Kundima-Apprehending of the candidate.

Kugundika-Seclusion and lessons from banang'oma on how to be chief.

Kung'wanila Ntemi-Enthronement.

\subsubsection{During the Enthronement, the Chief Elects Experienced People for the Following Undertakings}

Kufuha Maholelo-Blessing of royal regalia, singing of Kologosho, the bafumu song, and sacrifices to the great diviners like Luhinda.

Kumula Ntemi-Anointing the chief.

Kuhanga Mbula - Rain prophecy or divination for community. 
Kugabila Ha Mashigo ga Batemi-Offering at chief's graves.

Bumoga wa Ntemi (Busunzula)—Cutting of chief's hair.

Mashuda Na mbina ja Ndabaliga-People's feast and dancing.

Kwolechiwa Ku Banhu—Presentation to the people.

Kuja Lombo-Hunting expedition.

Ngole wa Lwambe - For one night ntemi sleeps with this woman chosen from royal family.

\subsubsection{The Manner the Chief was Chosen}

Traditionally, the chief was chosen among the son of daughters of the previous chief. The choice was made by banang'oma, royal family members who are official attendants and resembled modern day government cabinet members and ministers. Royal ministers rarely indicated who had to succeed the current ruler until his death such that the new chief was not groomed for the position and it dependent on the ministers for his training. He was also heavily influenced by traditional healers or bafumu (waganga in Kiswahili), the diviners and rainmakers. Along with such specialists, he also depended on pieces of advice and expertise from Balongo or blacksmiths. Blacksmiths forged agricultural tools, weapons and controlled fire. Such intermediaries would usually take the blame if mhola was challenged and would be punished for mistakes, poor predictions or bad advice that the Chief may have acted upon. In that way, the semi-divine chief was shielded from daily criticism, but if circumstances continued to deteriorate, it was possible that the chief could be dethroned. Historically, in most chiefdoms, chiefs controlled ivory trade, received tribute from community members, controlled use of fire with assistance from blacksmiths and depended on traditional healers for medicine. The relationship of the royal court of the chief with Blacksmiths and traditional doctors was pyramidal and linked spiritually as well as economically. It was reported that Sukuma culture explains that concepts like "spirits", "spirit possession", "spirit of ancestors", and "medicines" are considered to be sources of "power", "ability”, or simply "mystical magical power" and are essential to "rituals and the symbols, which help in making the "chief, traditional doctor, and blacksmith". Through the symbolic, the consecrated, traditional and with the medicine of traditional doctors, manufacturing (hoes and spear heads) and fire making of the blacksmiths including creation of mhola and rain by the chief, these authorities controlled the spiritual and economic vitality of their communities.

Some taboos, like anywhere else in Tanzania, every ethnic group has taboos. For example, in the study area it was taboo to take a shower in a well where they performed rituals. All graves are taboo to sit and stand on them. Such taboos safeguard and protect/conserve sacred places. All taboos are enculturated through the communities.

\section{Concluding Remarks and the Way Forward}

\subsection{Worship Areas}

There are several worship areas that include immovable physical objects associated to the ritual performance places, for example, wells like Luhuhi in Ilula village, Nkindwa biye tree in Ilula village, Magahi well in Isenge village, Isangijo hill at Isenge village, Dutwa well in Isenge village, Nyabusalu well in Igalukilo village and similar others. All these places need to be re-examined quickly through heirs and key elders in concerned society so as to deliberate on future establishment of protected and conserved areas. The granite rock boulders are being chopped off flakes for traditional medicine. Like worship areas, they present another avenue for preservation and continued use because people believe in their own accord.

\subsection{Future Prospects}

Some cultural heritage sites were identified. However, a lot more need to be explored in order to establish existence of physical cultural heritage sites in Busega district, Bariadi district and other areas in Simiyu region. For example, the grinding hollows, traditional game (bao) and the like are unique heritage assets. Such resources including undiscovered immovable archaeological objects would need presentation for sustainable preservation as well as conservation plans in line with Tanzania's Antiquities Acts, Antiquities Rules and Monuments of 1980 together with Cultural Heritage Policy of 2008.

\section{References}

[1] Lwanga-Lunyiigo, S.L. and Vansina, J.C. (1988) Bantu-Speaking Peoples and Their Expansion. In: Elfasi, M. and 
Hrbek, I., Eds., General History of Africa III: Africa from Seventh to the Eleventh Century, UNESCO, 140-162.

[2] Iliffe, J. (1979) A Modern History of Tanganyika. Cambridge University Press, London. http://dx.doi.org/10.1017/CBO9780511584114

[3] Ehret, C. (1984) Between the Coast and the Great Lakes. In: Niane, D.T., Ed., General History of Africa IV: Africa from the Twelfth to the Sixteenth Century, UNESCO, 481-497.

[4] Soper, R.C. (1968) Rock Gongs and a Rock Chute in Mwanza Region, Tanzania. Azania: Archaeological Research in Africa, 3, 175-189. http://dx.doi.org/10.1080/00672706809511492

[5] Chaplin, J.H. (1974) Prehistoric Rock Art of the Lake Victoria Region. Azania: Archaeological Research in Africa, 9, 1-50. http://dx.doi.org/10.1080/00672707409511714

[6] Soper, R.C. and Golden, B. (1969) An Archaeological Survey of Mwanza Region, Tanzania. Azania: Archaeological Research in Africa, Azania: Archaeological Research in Africa, 4, 15-79. http://dx.doi.org/10.1080/00672706909511507 


\section{Appendices}

Appendix I: Dutwa GPS Locations

\begin{tabular}{|c|c|}
\hline Place Name/Particulars & Coordinates \\
\hline NGASAMO HILL/NGASA AND WIFE'S GRAVE & $\begin{array}{l}\text { ELV. } 1413 \text { MASL } \\
\text { 36 M } 0595803 \\
\text { UTM } 9724960\end{array}$ \\
\hline NYANZAWE VILLAGE & $\begin{array}{l}\text { ELV } 1276 \text { MASL } \\
36 \text { M } 0598787 \\
\text { UTM } 9725262\end{array}$ \\
\hline NYANZAWE HILL TOP & $\begin{array}{l}\text { ELV } 1328 \text { MASL } \\
36 \text { M } 0599767 \\
\text { UTM } 9725806\end{array}$ \\
\hline $\begin{array}{l}\text { ILULA HAMLET, IMALAMATE VILLAGE } \\
\text { NKINDWABIYE TREE }\end{array}$ & $\begin{array}{l}\text { ELV } 1272 \text { MASL } \\
36 \text { M } 0597898 \\
\text { UTM } 9726080\end{array}$ \\
\hline $\begin{array}{l}\text { ILULA HAMLET, IMALAMATE VILLAGE } \\
\text { LUHUHI WELL }\end{array}$ & $\begin{array}{l}\text { ELV } 1268 \text { MASL } \\
36 \text { M } 0597618 \\
\text { UTM } 972968\end{array}$ \\
\hline OLD GOLD MINE ENTRANCE, NGASAMO VILLAGE & $\begin{array}{l}\text { ELV } 1221 \text { MASL } \\
36 \text { M } 0594135 \\
\text { UTM } 9724334\end{array}$ \\
\hline $\begin{array}{l}\text { IKUNGU LYA MBESHI B HAMLET, NG'WANG'WENGE } \\
\text { VILLAGE } \\
\text { SMALL STONES }\end{array}$ & $\begin{array}{l}\text { ELV } 1276 \text { MASL } \\
36 \text { M } 0599595 \\
\text { UTM } 9732264\end{array}$ \\
\hline -DO- & $\begin{array}{l}\text { ELV } 1265 \text { MASL } \\
36 \text { M } 0599573 \\
\text { UTM } 9732334\end{array}$ \\
\hline MASHAMBITI HAMLET, NG'WANG’WENGE VILLAGE & $\begin{array}{l}\text { ELV } 1254 \text { MASL } \\
36 \text { M } 0598458 \\
\text { UTM } 9730216\end{array}$ \\
\hline NG'WAMALWILO B HAMLET, N'WANG'WENGE VILLAGE & $\begin{array}{l}\text { ELV } 1266 \text { MASL } \\
36 \text { M } 0599441 \\
\text { UTM } 9729466\end{array}$ \\
\hline -DO- & $\begin{array}{l}\text { ELV } 1268 \text { MASL } \\
36 \text { M } 0599573 \\
\text { UTM } 9729238\end{array}$ \\
\hline -DO- & $\begin{array}{l}\text { ELV } 1274 \text { MASL } \\
36 \text { M } 0600743 \\
\text { UTM } 9728584\end{array}$ \\
\hline -DO- BORROW PIT & $\begin{array}{l}\text { ELV } 1282 \text { MASL } \\
36 \text { M } 0600160 \\
\text { UTM } 9727850\end{array}$ \\
\hline SHINYANGA HAMLET, NG'WANG'WENGE VILLAGE & $\begin{array}{l}\text { ELV } 1280 \text { MASL } \\
36 \text { M } 0601745 \\
\text { UTM } 9730322\end{array}$ \\
\hline -DO- & $\begin{array}{l}\text { ELV } 1287 \text { MASL } \\
36 \text { M } 0601311 \\
\text { UTM } 9730272\end{array}$ \\
\hline -DO- & $\begin{array}{l}\text { ELV } 1272 \text { MASL } \\
36 \text { M } 0601218 \\
\text { UTM } 9730876\end{array}$ \\
\hline -DO- & $\begin{array}{l}\text { ELV } 1270 \text { MASL } \\
36 \text { M } 0601466 \\
\text { UTM } 9731198\end{array}$ \\
\hline
\end{tabular}




\section{Continued}

IMALAMATE VILLAGE EAST OF NGASAMO HILL

ELV 1263 MASL

36 M 0598073

UTM 9724206

IMALAMATE VILLAGE SOUTH OF NGASAMO HILL

ELV 1247 MASL

36 M 0595386

UTM 9723960

ISADUKILO VILLAGE

ELV 1228 MASL

36 M 0591494

UTM 9722444

-DO-

ELV 1229 MASL

36 M 0592839

UTM 9724028

NGASMO VILLAGE, NGASAMO SECONDARY SCHOOL

ELV 1239 MASL 36 M 0593156 UTM 9724766

ILUJAMINZI HAMLET, NGASAMO VILLAGE

ELV 1227 MASL

36 M 0594243

UTM 9725052

-DO-

ELV 1227 MASL

36 M 0594630

UTM 9725436

-DO-

ELV 1235 MASL

36 M 0594772

UTM 9725358

MSANGA B HAMLET, SENGEREMA VILLAGE, GRINDING HOLLOWS (MANHE)

ELV 1267 MASL

36 M 0606748

UTM 9722524

-DO-

ELV 1272 MASL 36 M 0606813 UTM 972484

ISENGE VILLAGE, NG'WANAMANG'OLA GRAVE AND HIS WIFE'S GRAVE AT NG'WAMANG'OLA FOOT HILL, WEST SIDE

ELV 1294 MASL 36 M 0602910 UTM 9726434

WEST OF NG'WANAMANG'OLA GRAVE

ELV 1299 MASL 36 M 0602849 UTM 972638

ITEMELO HAMLET, ISENGE VILLAGE ITEMELO TREE

ELV 1252 MASL 36 M 0607547 UTM 9723964

NYABUSALU WELLS, IGALUKILO VILLAGE

ELV 1263 MASL 36 M 0607862 UTM 9723246

MSANGA A HAMLET, SENGEREMA VILLAGE, BAO (ISOLO)

ELV 1269 MASL 36 M 0606717 UTM 9722838

-DO- GRINDING HOLOWS

ELV 1270 MASL 36 M 0606753 UTM 9722764

-DO- TWO MEDICINAL ROCK BOULDERS

ELV 1278 MASL 36 M 0606283 UTM 9723490

NYANHIGA HAMLET, MAJENGO VILLAGE, KANDAWA HILL, BAO

ELV 1277 MASL 36 M 0605648 UTM 3723472

NYANHIGA HAMLET, MAJENGO VILLAGE, CAVE PLACE FOR WORSHIP

ELV 1289 MASL 36 M 0606395 UTM 9723674 


\section{Continued}

-DO- EAST OF KANDAWA HILL BAO

ELV 1273 MASL

36 M 0605754

UTM 9720536

NYALULE HILL, MAJENGO VILLAGE

ELV 1270 MASL

$36 \mathrm{M} 0605779$

UTM 9728444

IKINDILO HILL, MAJENGO VILLAGE

ELV 1260 MASL

36 M 0605559

UTM 9723204

SHAYAYI HILL, LUBAGA HAMLET, MAJENGO VILLAGE, WORSHIP PLACE

ELV 1310 MASL 36 M 0604997 UTM 9723766

NGULULYA HILL, ITEMELO A HAMLET, ISENGE VILLAGE MAGAHI WELL (LWINZI LWA BASHOLA)

ELV 1271 MASL 36 M 0606707 UTM 9724744

NAMA WELL, ITEMELO B HAMLET, ISENGE VILLAGE

ELV 1280 MASL 36 M 0607764 UTM 9727534

ISENGE B HAMLET, ISENGE VILLAGE, MAN EATER CAVE (IPILINGA LYA BALYA BANHU)

ELV 1289 MASL 360609073 UTM 9724394

NTI NIPU HAMLET, IGEGU VILLAGE, SAPIWI WARD

ELV 1315 MASL 36 M 0603868 UTM 3730390

KIHALAWA HILL, JIBISO HAMLET, IGEGU VILLAGE, PLACE FOR WORSHIP

ELV 1280 MASL

$36 \mathrm{M} 0602152$ UTM 9732858

IGEGU CENTRE HAMLET, IGEGU VILLAGE

ELV 1314 MASL 36 M 0605479 UTM 9732000

MPILINGO HAMLET, IGEGU VILLAGE

MINZI KU NTWE'S GRAVE, SITE FOR RAIN MAKING

DUTWA HILL, ISENGE VILLAGE

ELV 1309 MASL 36 M 0607096 UTM 9730616

1276 MASL

36 M 0607201 UTM 9724482

SOUTH OF DUTWA HILL, WELL - SITE FOR WORSHIP

ELV 1282 MASL 36 M 0607220

UTM 9724578

MAGAHI HILL, GRINDING HOLLOWS

ELV 1289 MASL $36 \mathrm{M} 0606606$ UTM 9727688

NORTH OF NG'AMANG'OLA HILL TOWARDS IGEGU VILLAGE

ELV 1372 MASL $36 \mathrm{M} 0604934$ UTM 9727408

-DO-

LLV 1315 MASL

36 M 0604954

UTM 9727534

ELV 1315 MASL 36 M 0604942 UTM 9727622

ELV 1312 MASL

-DO36 M 0604992 UTM 9727772

-DO- 


\section{Continued}

-DO-

1302 MASL

$36 \mathrm{M} 0605187$

UTM 9728092

-DO-

ELV 1302 MASL

36 M 0605276

UTM 9728236

-DO- CLOSE TO ISENGE-IGEGU BORDER

ELV 1328 MASL

36 M 0605024

UTM 9727362

-DO-

ELV 1325 MASL

36 M 0605008

UTM 9727342

ISENGE VILLAGE NORTH EAST OF NG'WAMANG'OLA HILL

ELV 1313 MASL 36 M 0605933 UTM 9727400

ISENGE NORTHEASTERN PART

ELV 1314 MASL 36 M 0606633 UTM 9727032

ISENGE VILLAGE

ELV 1303 MASL 36 M 0606780

UTM 9727156

ELV 1303 MASL 36 M 0606973 UTM 9727046

-DO-

ELV 1300 MASL 36 M 0606910

-DO-

ELV 1306 MASL

36 M 0606917

UTM 9726886

-DO-

ELV 1305 MASL

$36 \mathrm{M} 0606880$

UTM 9726820

NG'WAMANG'OLA HILL SLOPE ENE

ELV 1320 MASL 36 M 0606746 UTM 9726756

NG'WAMANG'OLA HILL SLOPE NORTHERN SIDE

ELV 1330 MASL 36 M 0606508 UTM 9726806

-DO-

ELV 1321 MASL 36 M 0606585

-DO- EAST

ELV 1297 MASL 36 M 0607067 UTM 9726640

-DO-

ELV 1295 MASL 36 M 0607086 UTM 9726552

ITEMELO B HAMLET, ISENGE VILLAGE, BORROW PIT

ELV 1288 MASL 36 M 0607691 UTM 9726142

MAGAHI HILL, ISENGE A HARMLENT, ISENGE VILLAGE-TWIGG CAMP VICINITIES

ELV 1284 MASL 360606542 UTM 9724740

-DO- GRAVE, THEN, SOUTHWESTERN PART GRINDING HOLLOWS AND BUILT WEATHER STATION WITHIN

ELV 1289 MASL GRINDING HOLOWS AREA 


\section{Appendix II: List of Participants in Focus Group Discussion and Key Informants}

1) One Focus Group Discussion was carried out at Igalukilo (Dutwa) with the following clan members and their Bahunda Chief:

From 3:00 to 5:55 p.m. $4^{\text {th }}$ March, 2012.

a) Maduhu Madaki (Bahunda-Chief)

b) Anthony Masanja (Elder for Chief)

c) Munyula Sabo (Bahunda clan member)

d) Michael Kishiwa Petro (Bahunda clan member)

e) Maduhu Mayenga (Bahunda clan member)

f) Saguda Buluguta (Bahunda clan member)

g) Lunyama Mahila clan member

B. Mapolu (Councilor and Bahunda clan advisor)

2) Key informants, Ngasa clan members and their Chief:

From 11:00 a.m. to 1:00 p.m. on $1^{\text {st }}$ March, 2012 with John Mandalu at Ngasamo village

From 9:00 to 11:00 a.m. with respondents (2 to 8) on $2^{\text {nd }}$ March, 2012 at Ngasamo village

From 2:00 to 4:00 p.m. with Chief Joseph Nkwabi and John Mandalu on $3^{\text {rd }}$ March, 2012 at Malili village

a) Joseph Nkwabi Mandalu (Chief, Ngasa clan)

b) John Mandalu (Ngasa clan member and Chief's younger brother)

c) Onesmo Juma

d) Paulo Mangashini

e) William Shilingwa

f) Malongo Magembe (Village Chair, Imalamate village)

g) George Masasila (Village Executive Office, Ng’wang; wenge village)

h) George (WEO, Dutwa Ward) 